\title{
Steel Flowers of the Empire: The Ottoman Ladies
}

\section{Dr. Çağdaş Lara Çelebi}

cagdas_celebi@hotmail.com

\author{
Doi:10.5901/ajis.2013.v2n9p200
}

\begin{abstract}
The current study aims to reveal that we can neither talk about a complete seclusion of the female population within the socioeconomic structure of the Ottoman Empire, nor present a single female image, which had represented all Ottoman women. To prove this, a comparative methodological analysis which exposes the similarities and differences of the Ottoman ladies' conditions both from each other and from their Western counterparts, is going to be applied. Due to having limited space, the subject will be evaluated within certain spheres and the focus will be mainly on the nineteenth century. After mentioning diverse rhetorics and analysis of some cliché convictions found in the traveler accounts, the paper will continue with the issues of female private property and polygamy, since the lacking of the former one and existence of the later one usually come to fore in the criticisms directed against the Ottoman society. Apart from these, it will become clear that the nineteenth century female educational improvements made positive contributions to Ottoman women's lives, but because of their narrow scopes and targets, in occupational sense, these developments could not have pledged great promises. Nevertheless, the historical sources imply Ottoman female population's partial involvement in the economic life of the Empire -long before the implementation of new educational reforms. The basic primary sources applied for this study mainly consist of the traveler accounts. Likewise some late nineteenth century annual reports of the American Protestant missionaries of the American Board of Commissioners for Foreign Missions and some nineteenth century periodicals were also resorted to.
\end{abstract}

In many respects the traveler accounts are sources, enlightening people about different cultures and civilizations. Hinging upon the educational level and personal characteristics of travelers, as well as aims of their journeys, topics and these topics evaluations naturally vary. Related with the subject, when we particularly focus on the Ottoman female life, we see that most of the travel books were written within the spheres of rhetoric of difference and similarity. These discourses were formulized at three levels: the underlined dissimilarities might be seen among the women, who were the members of the same (Pouqueville, 1820) or different Ottoman ethno-religious millet groups (Brewer, 1829; Frankland, 1829; Bond, 1828; Elliot, 1838; Fraser, 1838; Rolleston, 1856; Tietz, 1836; Mackenzie and Irby, 1867), or between the Ottoman and Western societies' women. In fact the very social structure of the Ottoman Empire, which consisted of diverse ethnoreligious groups helped the travelers, who endeavored to apply rhetoric of difference by epitomizing dissimilarities among the Ottoman women. As an example when we have a glance at travelers' ideas on the Greek Orthodox women of the Empire we see that, the Archadian ladies' pure mind and innocent smile, the Peloponnesians' beautiful physical appearance and virtue as well as devotion to their husbands -both in lifetime and after their demise- had attracted the attention of foreigners (Naval Chronicle, 1816).

In some travel accounts, the same rhetoric kind might serve to specific purposes, like espousing colonial policies of certain countries. Therefore the "knowledge structures", being used in the "meaning making process" of these sources were formulated to underpin certain aims. The travelers of this sort tended to make generalizations without capturing the variations among the Ottoman ladies in ethnic, religious and socio-economic senses. They generally offered readers a rhetoric of difference not among the Ottoman ladies, but between the Western and non-Western societies' women (Foucault, 2005; Smethurst, 2009; Edward and Graulund, 2011).

In addition to rhetoric of difference, sometimes similar manners or daily practices applied by the Ottoman women from different millets were highlighted. According to Josiah Brewer, for example, in the coastal town of Izmir, the garment style of the Muslim and Armenian ladies as well as the way in which they used henna for their nails resembled each other. Similar to this, in the Arabic lands the practice of some common local customs and superstitious beliefs of the native Bedouin and Christian women were pointed out (Brewer, 1830; Daughty, 2010). Few paragraphs before, the Peloponnesian Greek Orthodox women's allegiance to their husbands has been mentioned. In fact, together with "tenderness in motherhood", the notion of "loyalty to spouse", was frequently counted among the common features of the Muslim, Greek Orthodox, Jewish, Armenian etc., of all Ottoman women (Bisani, 1793; Naval Chronicle, 1816).

However, when we evaluate the overall socio-economic status of the Ottoman female figure in the historical sources, it appears that many researches aiming to place the female population in the Ottoman society, offer a static 
version of the past by having applied the Western attitude in a way, in which the nineteenth century Ottoman society as a whole is considered as "stagnant", "oppressive", and "underdeveloped". As a direct consequence of this, most Europeans had considered the position of women particularly in the pre-twentieth century Ottoman Empire as "depressed" (Macfarlane, 1850; Lumbroso, 2007). In many respects, these women, being confined in harems, by the walls of houses usually dealt with ornamental needle works and embroidery, passing their time by looking through windows at passengers and could communicate only with other females. So, their involvement in the socio-economic life was restricted. Furthermore, the Ottoman state religion, Islam, was seen as almost the sole regulator, being used to define the female role in the social life (Bisani, 1793; Lott, 1865; Tucker, 2002).

It is true that, in the period prior to Turkic populations' acceptance of Islam, along with their men, the females of these groups were riding, participating in hunting and swordmanship, partaking in the decision making process at the peace and war councils. Moreover, when it was necessary they engaged in warfare. In addition to these, hakan and hatun (the ruler and his wife), were used to represent their state together. From this perspective, relatively, the Ottoman period had witnessed alienation of women from the socio-economic life.

Changing religion may alter people's attitude and daily habits. It cannot however, play the role of being the sole regulator. The statements of some Europeans, who had sojourned the Ottoman lands in the nineteenth century, indeed, verify this assumption. Baron de Bois le Comte, a French diplomat who visited quite a few Ottoman cities during the Egyptian Crises in the 1830's for instance stated that, being Muslim, among some nineteenth century Arabic societies the female population was playing an active role in the public work (Oliver, 1801; Subaşı and Şenol, 2002; Badem, 2011; Çevik and Kaltakcı, 2011). Baron de Bois le Comte was not the only Westerner who realized this fact. According to Sir Adolphus Slade (1804-1877), who had served in the Ottoman fleet as a supervisor in the period between 1850-1866, Islam "respects women" and is not "particularly oppressive". He went further and suggested that,

\begin{abstract}
"We are in the habit of comparing it [Islam] with the Christian religion in the West, and drawing our inference there from. This is not fair: we should compare it with the Christian religion in the East -its cradle- where seclusion of women has ever been in vogue among the natives, whether Jews, Pagans, Christians, or Mussulmans" (Slade, 1833, p. 328).
\end{abstract}

It is true that the historical sources imply the reality of similar female social seclusions in the places, which were geographically close to the Ottoman lands. Certainly through the local people who share common mentality, as being meaning systems (Paloutzian, 2006) all religions in the vicinity of the region in question were in constant interaction with each other. This situation in fact facilitated the acceptance of some social values and judgements, which were influenced by religious beliefs, by most of the natives from different religions and, it also explains why the people of the same region tended to act in the same or similar direction/s. Some nineteenth century accounts for instance, mention the seclusion of the native Greek women during the Venetian sovereignty (1211-1669) in Crete Island. Accordingly, prior to the establishment of the Ottoman rule there, in their everyday lives the Cretan Greek women went out only for performing religious ceremonies, and other than such activities they used to spend their time at home (Pashley, 1837). The hyperbole found here is supposed to be eliminated and the peculiarity of the period must be taken into consideration, since the archival sources other than traveler accounts clearly underline the place of the Cretan women in the economic life of the island. As even in the fourteenth century, many of these ladies were participating in commerce and manufacturing (Mckee, 1998; Mckee, 2000).

Nevertheless, the above mentioned examples found in the traveler account reveal the fact that like everywhere else, in the Ottoman lands too, the mentality of local denizens had played a determinant role on social matters. By the same token, some travelers pointed "human character" out as a possible factor, setting some restrictions on Ottoman women's lives (Lott, 1865). According to G. L. Dawson Damer, for instance, in the 1840's

\footnotetext{
"There are three distinct kinds of conveyances to be met with in Stamboul. Some are so entirely closed by gilt lattice-work, that it is impossible to perceive the occupiers; these are considered to belong to the élite, and are called coochy. The second class of carriages, have on each side two circular openings, and one in front, but are without glasses; and you can distinguish three or four Turkish ladies reclining in them on soft cushions, covered with cashmere, silk, or chintz: they are called talika. The third kind, of which the name is araba, is a large, light sort of waggon, capable of holding a dozen people." (Damer, 1842, pp. 133-134).
}

In addition to the economic motive behind the usage of these carriages, Dowson Damer underlined that the first kind of carriages called coochy was preferred by the ladies, whose husbands were "jealous", whereas talikas were destined for the ones whose spouses were not interested in concealing them. Thus, to a certain extent, this situation 
inclines the importance of personal characteristics of the native people, which had given shape to the way of living, in our case, the lifestyle of women (Damer, 1842).

When we continue to evaluate the aforementioned example from a psychology perspective, certainly "jealousy" cannot be correlated with "love" all the time. Like the men who were jealous of their spouses, the men who did not show jealousy towards their spouses also felt love. Peoples' revealing of their love feeling may change from person to person. In the same vein, showing other feelings, such as respect and giving importance might vary with culture. In this regard, the members of the Eastern and Western societies may reveal a dissimilar attitude towards the same events. For this reason, it seems more likely that some behaviors of the Ottoman inhabitants were not understood and evaluated accurately by the Westerners. For example according to the sources, the issue of women' concealment was not only limited with physical environment, because as an "ideational image" too, women were not mentioned in the Ottoman society. As a consequence of this, many Europeans had underlined the fact that, unlike themselves, the Eastern men were not keen on talking about their wives with -foreigner or native- another man. From this situation they also inferred that the Ottoman men's spouses did not constitute an important part of their lives, as they did not disdain to talk about them. However, the truth of the matter was different: Muslim or non-Muslim, Ottoman men were proned not to mention their spouses to others and did not want to share their "privacy", due to the respect they felt towards their wives" (Subaş। and Şenol, 2002). Briefly speaking, as how Michel Foucault (1926-1984) posited that "deemed true" varies from place to place, so does the human emotions and attitudes (Mills, 1991). For the Ottoman men, what was "true" in this case, was the separation of the female sphere from the public sphere.

For the Ottoman female seclusion issue probably it will not be wrong to suggest changing of geographical conditions in the former times -moving from Central Asia to new lands like Anatolia, Balkans-, and passage to sedentary life as other factors, led to the partial alienation of Ottoman women within the social life. By re-defining their roles, all these developments in due course had seemed to shape the social borders of the female figure in daily life (Subaşı and Şenol, 2002).

Apart from all these, what many travelers, historians and researchers have emphasized is the essentiality of individually owned "private property" as a fact, strengthening women' status and image in the society. When the Ottoman society is analyzed from this perspective, the historical sources clearly reveal the existence of female-owned private property, which could be freely possessed, sold or donated. Among the "commercial properties" of the female population existed some farms, vineyards, windmills, orchards, olive tree gardens and et cetera (Göçek, 1994). Without digression note that in fact, this situation proves the fallacy of Friedrich Engels's (1820-1895) theory, which pointed out the correlation between the emergence of monogamous marriages in history and oppression of the female rights, also in the Ottoman lands. For Engels through monogamy, among his offsprings, men obtained the right to designate the ones, who would be his heir/s. And in return, by hindering female accession to property the supremacy of the men within the society was achieved (Engels, 1908).

As stressed by Judith E. Tucker, Engels's one of the major theoretical weaknesses was his ruling out of "modes of production" and "meanings of property", which might change from place to place (Tucker, 2002). Perhaps it will not be wrong to assume the essentiality and diversity of societies' "value judgments" as another omitted point in Engel's theory, since direct correlation between "respecting someone" and "having property" cannot be always correlated. The general value judgment of the Ottoman society verified this because, having immovable property or acquiring wealth was not the only reason, causing other people to show respect. In this regard, having kinship ties with certain lineage, or being the family elder for instance, were countable among the factors, which increased peoples' importance in the eyes of others. This tendency was perceivable both among the male and female populations of the Empire (Tucker, 2002). When "being family elder" is examined as criteria, it appears that in some regions, like the inner parts of Anatolia, the mothers-in-law were considered almost as "sole heads" of their families. Although like the Muslim families, the Ottoman non-Muslim families (both Jewish and Christian) too had patriarchal structure, the mothers-in-law seemed to under-control everything within the families. The young female members of the families, such as brides, on the other hand, particularly until bearing a child had rather limited rights within the family environment and were guided in all matters by their elders (Walpole, 1818; Elliot, 1838; Bardavit, 2007).

Within the radius of marriage we should briefly dwell on the issue of polygamy, because this marriage type was seen as a factor deteriorating to a great deal the social position of the Eastern women -including the Ottoman ladies. To begin with, polygamy was not peculiar to Muslim men. Although very few in number, the historical sources clearly documented the existence of some non-Muslim polygamies. The applied laws in the Ottoman domains however, set some limitations for polygamy, and in according with these monogamy was recognized only if the circumstances necessitated the marriage of this sort. Furthermore, the lady, who did not consent to unite to a man in such conditions had reserved right to reject the polygamous marriage. According to the historical sources, most of the Ottoman ladies had 
preferred monogamous marriage, and unlike the general conviction, polygamy was not all that widespread in the Ottoman society. In fact, in the late nineteenth century monogamy was not only espoused by literate female figures but also by some ulema (the Islamic scholar) members, who adopted a stance next to Ottoman women. Fatma Aliye Hanım -later on, Fatma Aliye Topuz (1862-1936)- for instance, did not hesitate to criticize men, who had preferred polygamy by using pejorative words, like "roosters", while describing the men with one wife as "pigeons" (Montagu, 1761; Voltaire, 1764; Elliot, 1838; Nicol, 1856; Voltaire, 1860; Erdoğdu, 1994; Philips and Jones, 2005; Marvel, 2011).

Undoubtedly the tone of traveler accounts show a huge range of diversity and due to having limited space here, we cannot mention all these genres. Despite this, travelers' inclination to see Eastern ladies -including the Ottoman ones- as "exotic" and "picturesque" must be mentioned. As while mentioning the subjects which were relating to these ladies, particularly the themes of "seclusion" and polygamous marriages, travelers used to "exotize" the general atmosphere. Certainly while doing this some travelers did not expose any ulterior motive. For better understanding of this Eurocentric inclination, the "ladies in the Turkish bath concept" constitutes a good sample to briefly dwell on. Since, when the issue was Turkish bath, generally travelers depicted a picture of a place with full of "hypersexual ladies". In their visitations to the places alike in the Western lands however, they did not pursue analogous ways to define the scene. For example, the early nineteenth century historical sources point out the existence of natural hot baths, which were used by both males and females in the Hungarian lands. In these baths, the spheres of different genders were not separated from each other. On condition of adults' covering their certain parts of bodies, the baths could be used by men and women as well as children "simultaneously". Despite this, the mentioned baths were only defined with plain language, as a place to bathe (Elliot, 1838). Undoubtedly, among the Europeans also existed some travelers like Lady Mary Wortley Montagu (16891762) who offered, even prior to the Victorian period (1837-1901) in which the British travelers had developed more empathy towards the Ottoman society -especially its Muslim fraction-, objective and logical scene of the Turkish baths. She clearly underlined the impossibility of seeing something carnal in such public places, which were full of "noisy children" and were allocated to people for sanitary purposes (Ezer, 2002).

Probably lack of school education among the Ottoman ladies contributed to the development of this mistaken female image found in the Western sources. Before the nineteenth century in the Ottoman realm, including Balkans, apart from the sibyân schools (صبيان, primary schools) the formal school education was exclusively extended to male students. Hence, in some places, among the Ottoman women it was difficult to observe even the existence of basic education, which meant reading and writing. For the non-Muslim female students too the situation was similar (Walpole, 1818; Bond, 1828; Elliot, 1838; Rolleston, 1856; Taitz, and Henry and Tallan, 2003; Çelebi, 2011b; Şanal, 2013). Depended on the economic conditions of their families, however, some ladies could receive private education, and thus, knew some foreign languages like French, Italian, English and could play some musical instruments such as piano forte, flute and guitar (Bisani, 1793; Macgill, 1808; Kurt, 2012).

In 1842 the first state-initiated midwifery course was opened within the structure of Tibhâne-i Amire. Its first graduates consisted of ten Muslims and twenty-six non-Muslims. Few years later in 1858 the first rüşdiyye school (شديك, secondary schools) for girls, namely Cevri Kalfa Inas Rüşdiyesi, offering rudimentary religious education was inaugurated by the Ottoman state. In the rüşdiye school for girls both Muslim and non-Muslim women could serve as teacher especially for the needlecrafts courses. Furthermore, from the 1871 onwards, some of these schools were governed by female administers. As time passed, existence of the secondary school for girls necessitated the opening of female teachers' training school, whose graduates would serve at rüşdiyyes. Consequently, Darülmuallimat (دارالدعاتS) was opened in 1870. In the same years, another school was offered to female students: the School of Arts and Handicrafts (Sanayi Mektepleri). By instructing occupational courses like carpet weaving, sewing, cooking and embroidery, this school was designed to prepare female students for the "labor market" (Akyüz, 1999; Çolak, 2002; Semiz and Kuş, 2004; Bakacak, 2009; Güven and Akagündüz, 2011; Marvel, 2011; Kurt, 2012; Şanal, 2013).

In fact, the nineteenth century female educational developments had not only been espoused by the Ottoman state's and non-Muslim communities' initiatives but also by the Western female educational activities. To a certain degree improvements in the American and European female education of the epoch directly contributed the Ottoman female education. Through the missionary activities, the first girls' schools of the Ottoman Empire were inaugurated -in Beirut in 1830 and in İstanbul in 1832- by the missionaries of the American Board of Commissioners for Foreign Missions (hence, ABCFM) (Report of the American Board, 1853; Sixty-First Annual Report; 1871; Sixty-Second Annual Report; 1872; Alan and Bolat, 2011). Towards the last decades of the nineteenth century missionary sources mention the existence of seven boarding schools for girls and two hundred and four day or common schools which were attended also by the female pupils in the Ottoman lands (Sixtieth Annual Report, 1870). In addition to ABCFM, other missionary groups too opened schools at the kindergarten, primary and secondary school levels. To these schools both Muslim and non-Muslim pupils 
could attend. So, the Western education had effects on both Ottoman Muslim and non-Muslim (Christian and Jewish) female educational systems (Elliot, 1838; The Home and Foreign Record, 1853).

Despite all these developments, still in the late nineteenth century, the "gender role" or "behavior expectations" (Myers, 1993) for females, did not seem to undergo a change since, the chief motive beneath the overall developments in Muslim or non-Muslim female education seemed to be rather a preparation of qualified wives and mothers (Karaca, 2011). This sentiment was not only prevailing among the Ottoman millet communities and some of their institutions but was also supported by the intellectuals. The prominent Muslim intellectuals of the Tanzimat Era (1839-1876), such as Namık Kemal (1840-1888), Munif Pasha (1828-1919), Safvet Pasha (1814-1883) and Ziya Pasha (1825-1880) for example, considered female education as a remedy for regression of the society (Çelebi, 2011; Şanal, 2013). In reality, in the West too, the exponents of these ideas, who were defending their stance, still could be found. Some significant Western intellectuals such as August Comte (1797-1857) and John Stuart Mill (1806-1873) were also accentuating the essentiality of the espousal, which must be supplied by women for their husbands. Thereby the main female responsibilities were: "perfecting men" and "raising children" (Mill, 1866; Alger, 1867). However, it is vital to stress that the new trends particularly in America developed in a new direction, in which the female roles were thought to be more germane to the personal and individual life of women and, the emphasis was made on gender equality. The essentiality of "wifehood" and "maternity" were still considered as important characteristics of women, but they were not seen as sine quo non female features (Oscanyan, 1857; Alger, 1867).

The female educational developments cannot be segregated from the newly emerged ideologies of the epoch. The late nineteenth century Ottoman imperial lands as a whole had witnessed the permeation and diffusion of nationalistic ideas, originated from Europe, among different millet groups. In addition to nationalism, the same period witnessed the emergence of feminism among the Ottoman Muslim and non-Muslim female populations. By the time passed the immingle of these two tendencies, nationalism and feminism, had oriented the way of thinking towards certain ideological path. Parallel to these, through mothers' education, the essentiality of feeding children's mind with nationalistic ideas from the beginning, came to fore. The basic idea was: while growing up, if a child's mind was shaped by such ideas, s/he would be a beneficial individual for the society and, first of all, for his/her own ethno-religious community (Rowe, 2000; Balta, 2007; Exertzoglou, 2007; Çelebi, 2011a; Çelebi, 2011b; Marvel, 2011).

No uniformity however, emerged among the Ottoman feminist women because, there existed more than one type of nationalistic discourses at that time. The crystallization of the separate national feelings directed especially the literate women to support the national values of their own millet communities rather than the general Ottoman advancement. The Armenian women, for example, were tried to be encouraged by establishing ties between themselves and the Armenian

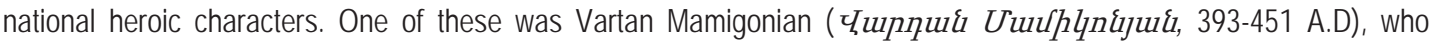
fought against the Persians as a defender of Christianity and died in 451 A.D. Later on he was consecrated as a saint by the Armenian Church because, after his death he became the symbol of the liberation of the Armenian Christianity (Gaidzakian, 1898; Ohanyan, 2011). So, Mamigonian's story was adapted to the Ottoman case, "to demonstrate the connection between Armenian national autonomy and Armenian women's liberation" (Rowe, 2000, p. 159) in the late nineteenth century.

In the same vein, some prominent Muslim female intellectuals of the period, such as previously mentioned Fatma Aliye Hanım, were emphasizing the rightness of their "own cultural principles", so as to say the Islamic values. One of the leitmotifs of her famous work Nisvân-I İslâm (1891) which was serialized in Tercüman-ı Hakikkat Newspaper (ترجمان (حقيقت), and in the years to follow was translated to Arabic and French, was the misperception of the Muslim women by the Europeans. According to her what the Western people saw was not the right but only the "distorted image" of the real Muslim women. For a remedy, she was suggesting Ottoman Muslim women to learn French language and Islamic law precepts. As by dint of this, misperceptions could be rectified and the truths could be properly explained (Marvel, 2011).

Within this scope for a comparison when we glance at the nineteenth century America, it appears that the "perfection of race" and "instilling in children own cultural values" were also emphasized among the American female duties (Alger, 1867; Smith, 2006). Moreover, in the period in question similar to that of their Ottoman Muslim and nonMuslim counterparts, the American ladies too had begun to evaluate the intellectual works of the yore to strength their own ideas. The sixteenth century German oculist, theologian and magician Henricus Cornelius Agrippa von Nettesheim (1486-1535) was one of these intellectuals (Morley, 1856) because, with his works he was defending the female position in the society in the age, in which compared to men, women's probability of being under the influence of spiritual evils, was seen higher. As it was openly stated that: "Sunt \& aliis, alias rotiones assignantes, cur in maiore multitudine reperiantur fœminæ superstitiosæ quàm uiri. Prima est, quia pronæ sunt ad credendum, \& quia principaliter dæmon quærit corrumpere fidem, ideo potius eas aggreditur..." (Krämer and Sprenger, 1576, p. 70). The ideas of Henricus 
Cornelius Agrippa appear to be quite avant-garde for his era. He promoted the idea of males' and females' having equal status and rights in the social structure. He even suggested that:

"PREMIĖREMENT, je dis que la femme est autant supérieure à l'homme, que le nom de la première femme est audessus de celui du premier homme: en effet, Adam signifie Terre, et Eve signifie Vie. La femme est donc autant supérieure à l'homme, que la vie est au -dessus de la terre." (Agrippa, 1801, p. 4).

To continue with the Ottoman lands, to some degree the effects of female education in the last decades of the nineteenth century began to bring results in ideological sense. In occupational sense on the other hand, the new schools and educational ameliorations could not lead to immediate and tremendous change in Ottoman women's lives. Despite their lack of general formal school education, like in the nineteenth century in the pre-nineteenth century too, the Ottoman women from all millets were able to do several professions: they had worked particularly as midwives, nurse, and tailors. Many of them also served as "active workers" -in sericulture, cloth or textile production, carpet and wax manufacture as well as in handicraft trade. According to Karl von Scherzer, who sojourned in İmir and its vicinity in 1873, only in the Uşak District (kaza) there were about 3.000 carpet weaver female workers. Furthermore, in places where economy was primarily based on agriculture, inevitably the female population had dealt with agricultural activities and sold goods at the local bazaars. Apart from these, depending on region and place, it was also possible to see some women who were working as court-crier, seam-stress, steel-welder, teacher as well as calligrapher, poet and composer. The historical sources mention the existence of about forty well-known Ottoman female poets, who had lived in the period between fourteenth to nineteenth centuries (The Edinburg Review, 1810; Bond, 1828; Damer, 1842; Rolleston, 1856; Göçek, 1994; Scherzer, 2001; Subaşı and Şenol, 2002; Taitz, Henry and Tallan, 2003; Maydaer, 2006; Dingeç, 2010; Çevik and Kaltakcı, 2011). The involvement of women in professions related with art was not limited with this. In the second half of the nineteenth century a female music band, which was composed from sixty ladies and was formed by the order of Sultan Abdülmecid's (1823-1861) daughter Zeynep Sultan. An interesting point to be observed here is that in accordance with the sources, the female members of this band were wearing male bandsman garments (Çevik and Kaltakcl, 2011). In addition to being a music band member, there were other slightly unusual and advanced professions -in terms of the pre-nineteenth century standards- performed by the Ottoman women. It is known that,

"A small group of women in the lands of the East practiced some form of medicine. In Jerusalem, Jewish women were mentioned as kahhala, a title specific to eye doctors. Amon Cohen suggests that these women might have originally been cosmeticians who were proficient in the use of antimony (kohl) for eye makeup and thus became skilled in treating eye diseases" (Taitz, Henry and Tallan, 2003, p. 186).

The Ottoman society was not unfamiliar with female healers, who were dealing with both male and female diseases. However the aforementioned example implies the presence of expert female healers, who had developed medical techniques to cure specific illnesses of both genders in the pre-nineteenth century (Shefer, 2006).

Despite these, in some cases the obtainment of the Ottoman females, who were performing different professions, is not an easy task. Although for example, throughout the Empire many Ottoman women from all millet communities individually or collectively were involved in different sorts of textile manufacture, their labor and activities as a whole might not leave a visible trace to the archival sources. About the elusiveness of the female labor some historians suggest that, not everywhere but in some places generally the output produced by women were not able to reach the local markets. Hence, despite the fact that they were actively involved in the production process, their performances were not discernible enough (Göçek, 1994).

In fact, in the Western world too, throughout the centuries certain occupations or "the lighter labors" were intrusted to women. Although in America the female pioneers of medical and law school graduates, for instance, had started to be seen from the mid-nineteenth century onwards, -namely Elizabeth Blackwell (1821-1910) and Arabella Mansfield (or Belle Aurelia Babb Mansfield, 1846-1911)- generally the Western female population too, could not deal with all sorts of occupations they desired. Therefore, still in the second half of the nineteenth century they were stressing that women's occupational preferences should not be restrained and they should not be "appendage to men" (Voltaire, 1860; Alger, 1867; Smith, 2006; Ford, 2008).

To sum up, the results of our investigation, first of all, show that the Ottoman society had its own peculiarities, which to a certain degree had shaped, differentiated and partly alienated the female sphere within the public sphere. The female population in the Ottoman lands however, was not completely barred from the socio-economic life. Moreover, parallel to the developments taking place in other parts of the world, particularly in fin de siècle Ottoman society, the Ottoman ladies as a whole partake in new activities and their participation in the socio-economic life had accelerated. 
Although many traveler accounts represent the delusion of Eurocentric approach, the fragments of true information, which reflect the real place of the Ottoman ladies can be attained. Undoubtedly the rhythms of the life in Eastern and Western societies were not identical, so were the social places of their members. Difference in this sense did not mean that the members of the former one were totally suppressed whereas the later one enjoyed complete liberty. As being the component of socio-cultural life, the subjects, which are relating to women must be interpreted in the environment they found, by taking their own conditions into consideration.

The current paper has mainly pointed out the Western people's ideas found in the traveller accounts. In fact, the Ottoman men, who had opportunity to make observations on the status of the Western female populations also verify the asserted ideas of this study. After his observations concerning the American women in the 1860's, what Ottoman Armenian writer Hachik Oscanyan (1818-1895, later on Christopher Oscanyan) stressed in his book with a little bit humour for the Ottoman Muslim women, seemed to be accurate for all Ottoman ladies -regardless their ethno-religious millet communities:

"A Turkish lady is eminently queen of her dominions, sometimes even a despot -and most independent on all occasions, both public and private... when they go out; public sentiment entirely protect them; for, if any one should accost them rudely, the commonest citizen would immediately turn avenger....They seem, indeed, to be privileged class. Wherever they appear the men must retire -and woe to the man who ventures upon a warfare of words with a Turkish woman; for her tongue has no bounds, and her slipper is a ready weapon of chastisement; and no man would dare to repel the attack" (Oscanyan, 1857, p. 229).

Perhaps for the conclusion of this study, it will be appropriate to quote one Sephardic Jewish proverb, which was being used among the members of the Jewish millet in Anatolia, as it seems to reveal the status of the Ottoman women within the society as a whole: "Famiya sin mujer es una lanterna sin luz" (Bardavit, 2007, p. 141) (Family without a woman is a lightless lantern).

\section{References}

Agrippa, H. C. 1801. De l'excellence et de la supériorité de la femme. (Roétitg, Trans.). Paris: Chez Louis. Alger, W. R. 1867. Women in Public Life. The Christian Examiner, (83), 342-365. Analectic Magazine and Naval Chronicle. 1816. 7 (37). Bisani, A. 1793. A Picturesque Tour through Part of Europe, Asia, and Africa. J. Davis: London. Bond, A. 1828. Memoir of the Rev. Pliny Fisk, A. M. Late Missionary to Palestine. Boston: Crocker and Brewster. Brewer, J. 1830. A Residence at Constantinople, in the Years 1827. New Haven: Durrie \& Pack.

Damer, G. L. D. 1842. Diary of a Tour in Greece, Turkey, Egypt and the Holy Land (vol. 1, 2nd edn.). London: Henry Colburn. Daughty, C. M. 2010. Travels in Arabia Deserta (vol. 1). Cambridge: Cambridge University Press. (First published in 1888). Elliot, C. B. 1838. Travels in the Three Great Empires of Austria, Russia and Turkey (vol. 1). London: Richard Bentley. Engels, F. 1908. The Origin of the Family Private Property and State. (E. Untermann, Trans.). Chicago: Charles H. Kerr \& Company. Fraser, J. B. 1838. A Winter's Journey (Tatar) from Constantinople to Tehran (vol.1). London: Richard Bentley. Frankland, C. C. 1829. Travels to and from Constantinople in the Years 1827 and 1828 (vol. 1). London: Henry Colburn. Gaidzakian, O. 1898. Illustrated Armenia and the Armenians. Boston: N.P..

Krämer, H. and Sprenger, J. 1576. Mallevs Maleficarvm in Tres Divisvs Partes. Venice: N.P.

Lott, E. 1865. Harem Life in Egypt and Constantinople (vol. 1). London: Richard Bentley.

Macgill, T. 1808. Travels in Turkey, Italy and Russia, During the Yeas 1803, 1804, 1805 and 1806. London: John Murray.

Macfarlane, C. 1850. Turkey and its Destiny (vol. 2). London: John Murray.

Mackenzie, G. M. and Irby A. P. 1867. Travels in the Slavonic Provinces of Turkey-in-Europe. London: Bell and Daldy.The Edinburg Review, or Critical Journal for April 1808....July 1808. 1810. (vol. 13, 3rd edn.), pp. 318-335. Edinburg: D. Willison.

Mill, J. S. 1866. Auguste Comte and Positivism (2nd edn.). London: N. Trübner \& Co..

Montagu, M. W. 1761. Letters and Works of Lady Mary Wortley Montagu (vol. 1), Lord Wharncliffe (ed.). London: Henry G. Bohn.

Morley, H. 1856. The Life of Henry Cornelius Agrippa von Nettesheim, Doctor and Knight, Commonly Known as Magician (vol. 1). London: Chapman and Hall.

Nicol, M. 1856. Ismeer, or Smyrna and its British Hospital in 1855. London: James Madden, 1856.

Nineteenth Annual Report of the American Tract Society (vol. 19). Boston: Perkin \& Marvin.

Oliver, G. A. 1801. Travels in the Ottoman Empire, Egypt, and Persia Undertaken by Order of the Government of France, During the First Six Years of the Republic (vols. 1-2). London: Longman and O. Rees.

Oscanyan, C. 1857. The Sultan and His People. New York: Derby \& Jackson.

Pashley, R. 1837. Travels in Crete (vol. 1). London: John Murray.

Pouqueville, F. C. H. L. 1820. Travels in Greece and Turkey. London: Colburn and Co. Report of the American Board of Commissioners for Foreign Missions, Presented at the Forty-Fourth Annual Meeting Held in Cincinnati, Ohio October 4-7, 1853. Boston: Press of T. R. Marvin. 
Rolleston, G. 1856. Great Britain War Office Report on Smyrna, London: G. E. Eyre \& W.Spottiswoode.

Scherzer, K. von. İzmir 1873, 2001. (İ. Pınar, Trans). İzmir: İzmir Büyük Şehir Belediyesi Kültür Yayını.

Sixtieth Annual Report of the American Board of Commissioners for Foreign Mission, Presented at the Meeting Held a Brooklyn, New York, October 4-7, 1870. Cambridge: Riverside Press.

Sixty-First Annual Report of the American Board of Commissioners for Foreign Missions, Presented at the Meeting Held at Salem, Massachusetts, October 3-6, 1871. Boston: Riverside Press.

Sixty-Second Annual Report of the American Board of Commissioners for Foreign Missions Presented at the Meeting Held at New Haven, Connecticut, October 1-4, 1872. Boston: Riverside Press.

Slade, A. 1833. Records of Travels in Turkey, Greece \& c. and of the Cruise in the Black Sea with the Captain Pasha in the Years 1829 , 1830 and 1831 (vol. 2, 2nd edn.). London: Saunders and Otley.

The Home and Foreign Record of the Free Church of Scotland, 1853 (vol. 3), Edinburg: James Nicol.

Tietz, F. 1836. St. Petersburg Constantinople and Napoli Di Romania in 1833 \& 1834: A Characteristic Picture, Drawn During a Residence There. New York: Theodore Foster.

Walpole, R. 1818. Memoirs Relating to European and Asiatic Turkey and Other Countries of the East (2nd Edn.). London: Longman.

Voltaire, F. M. A. de. 1764. A Philosophical Dictionary (vol. 6). (M. de Voltaire, Trans.). Glasgow: Robert Urie.

Voltaire, F. M. A. de. 1860. Ouvres Complètes de Voltaire (vol. 13). Paris: Librairie de L. Hachette et Cie.

Akyüz, Y. (1999). Osmanlı Son Döneminde Kızların Eğitimi ve Öğretmen Faika Ünlüer'in Yetişmesi ve Meslek Hayatı. Milli Eğitim, (43), 12-32.

Alan, G. and Bolat, G. (2011). The American Board and the Ottoman Women's Education. History Studies (Relationships of USA and the Middle East Special Issue), 105-117.

Badem, C. (2011). Amiral Adolphus Slade'in Osmanlı Donanmasındaki Hizmetleri ve Osmanlı İmparatorluğu Üzerine Gözlemleri. Türkiyat Mecmuası, (21), 115-140.

Bakacak, A. G. (2009). Cumhuriyet Dönemi Kadın İmgesi Üzerine Bir Değerlendirme. Ankara Üniversitesi Türk İnkılâp Tarihi Enstitüsü Atatürk Yolu Dergisi, (44), 627-638.

Balta, E. 2007. Sinasos, Mübadeleden Önce Bir Kapadokya Kasabası, İstanbul: Birzamanlar Yayıncılık.

Bardavit, B. 2007. Judeo-Espanyol Atasözlerinde 1850-1950 Arası Çorlu Musevileri'nin Günlük Yaşamı. İstanbul University, İstanbul: PhD. Thesis.

Çelebi, Ç. L. 2011a. Ottomanism and Inter-Communal Relations: Sanjak of Kayseri in the Decade of 1870-1880, Berlin: Lambert Academic Publishing.

Çelebi, Ç. L. 2011b. The Educational Developments in the Sanjak of Kayseri 1870-1880, Berlin: Verlag Dr. Müller.

Çevik, A. E. and Kaltakcı, M. Y. (2011). Türk Musikisi Geleneğinde Kadın ve Kadın Bestekarlar. Türkiyat Araştırmaları Dergisi, (29), 609638.

Çolak, B. 2002. Portraits of Women in the Late Nineteenth Century Ottoman Empire from the Pen of Ahmed Midhat Efendi. Bilkent University, Ankara: M.A Thesis.

Dingeç, E. (2010). Osmanlı Toplumunda Kadınların Üretime Katkıları. History Studies, 2(1), 2010, 9-30.

Edward, J. D. and Graulund, R. 2011. Introduction: Reading Postcolonial Travel Writing. In Justin

D. Edward and Rune Graulund (Eds.), Postcolonial Travel Writing: Critical Explorations pp. 1-16. London: Palgrave Macmillan.

Erdoğdu, I. 1994. Harput'ta Gayrimüslimler (1823-1868). Hacettepe University, Ankara: M.A Thesis.

Exertzoglou, H. 2007. Metaphors of Change: 'Tradition', and the East/West Discourse in the Late Ottoman Empire. In Çağlar Keyder and Anna Frangudaki (Eds.), Ways to Modernity in Greece and Turkey: Encounters with Europe 1850-1950 pp. 43-59. New York: I. B. Tauris

Ezer, Ö. 2002. Challenging the Image of Turkish Women: Travel Accounts of Female Authors (1762-1935). Middle East Technical University, Ankara: M.A Thesis.

Ford L. E. (Ed.). (2008). Encyclopedia of Women and American Politics. New York: Facts On File.

Foucault, M. 2005. Order of Things: An Archaeology of the Human Sciences, New York: Routledge.

Göçek, F. M. 1994. An Archival Source for Locating Women in Middle Eastern History: Eighteenth

Century Inheritance Registers. In Jean-Paul Pascual (Ed.), Vie materielle et patrimonies dans l'empire ottoman pp. 1-22. Paris: CNRS.

Güven, I. and Akagündüz, Ü. (2011). Osmanlı Devleti'nde Kadınlara Yönelik Tarih Öğretimi

Çabaları ve Ali Seydi Bey'in Kızlara Mahsus Tarih-i Osmani Adlı Eseri. Ankara Üniversitesi Osmanlı Tarihi Araştırma ve Uygulama Merkezi Dergisi, (26), 141-165.

Karaca, Ş. (2011). Fatma Aliye Hanım'ın Türk Kadın Haklarının Düşünsel Temellerine Katkıları.

Karadeniz Araştırmaları, (31), 93-110.

Kurt, S. K. 2012. II. Abdülhamid Döneminde Kız Rüşdiyeleri. Akademik Bakış Dergisi, (29), 1-19.

Lumbroso-Barzilai, R. 2007. Turkish Men, Ottoman Women: Popular Turkish Historians and the Writing of Ottoman Women's History. PhD. Thesis, Los Angeles: University of California.

Marvel, E. P. 2011. Ottoman Feminism and Republican Reform Fatma Aliye's Nisvân-ı İslam. Ohio State University, Ohio: M.A Thesis. Maydaer, S. (2006). Osmanlı Klasik Dönemde Kadınların Servet Edinme Yolları (Bursa Örneği). Uludağ Üniversitesi İlahiyat Fakültesi Dergisi, 2 (15), 1-17.

Mckee, S. (1998). "Women Under Venetian Colonial Rule in the Early Renaissance: Observations on their Economic Activities", Renaissance Quarterly, (51), 34-67. 
Mckee, S. 2000. Uncommon Dominion: Venetian Crete and the Myth of Ethnic Homogeneity. Philadelphia: University of Pennsylvania. Mills, S. 1991. Discourse of Difference an Analysis of Women's Travel Writing and Colonialism. New York: Routledge.

Myers, D. G. 1993. Social Psychology (4th edn.). New York: McGraw-Hill.

Nash, G. 2006. Politics, Aesthetics and Quest in British Travel Writing on the Middle East. In Tim Youngs (Ed.), Travel Writing in the Nineteenth Century: Filling the Blank Spaces, pp. 55-69. New York: Anthem Press.

Ohanyan, H. 2011. Vartanantz. St. Vartan Voice, Oakland: St. Vartan Armenian Church.

Ortaylı, İ. 2006. Osmanlı'yı Yeniden Keşfetmek. İstanbul: Timaș Yayınları.

Paloutzian, R. F. 2006. Psychology, the Human Sciences, and Religion. In Philip Clayton and

Zachary Simpson (Eds.), The Oxford Handbook of Religion and Science, pp. 236-252. New York: Oxford University Press.

Philips, A. A. B. and Jones J. 2005. Polygamy in Islam (2nd edn.). Riyadh: International Islamic Publishing House.

Rowe, V. 2000. The New Armenian Woman: Armenian Women's Writing in the Ottoman Empire, 1880-1915. PhD. Thesis, Toronto: Toronto University, Toronto: PhD. Thesis.

Semiz, Y. and Kuş, R. (2004). Osmanlı'da Mesleki Teknik Öğretimi İstanbul Sanayi Mektebi (1869-1930). Türkiyat Araştırma Dergisi, (15), 275-295.

Shefer M. The Ottoman Empire. In Suad Joseph and Afsāna Nağmābādī (Eds.), Encyclopedia of Women \& Islamic Cultures: Family Body, Sexuality and Health pp. 190-191. Leiden: Brill.

Smethurst, P. 2009. Introduction. In Julia Kuehn and Paul Smethurst (Eds.), Travel Writing, Form, and Empire: The Poetics and Politics of Mobility pp. 1-18. New York: Routledge.

Smith, S. F. 2006. She Moves the Hands that Move the World: "Antebellum Child-Rearing. Images of Mother and Child in NineteenthCentury Periodicals for Mothers. PhD Thesis, Minnesota: Minnesota University.

Subaşı, T. and Şenol, A. (2002). Baron de Bois le Comte'un Raporlarına Göre, II. Mahmut Döneminde Osmanılı Kadını. International Journal of Human Sciences, 9(1), 1032-1048.

Şanal, M. (2013). Women's Teacher Training in the Ottoman Empire during the Westernization Period, c. 1839-1920. International Journal of History, 5(1), 325-348.

Taitz E., Henry, S. and Tallan, C. 2003. The JPS Guide to Jewish Women: 600 B.C. to 1900 C.E. Philadelphia: The Jewish Publication Society.

Tucker, J. E. 2002. Women in Nineteenth Century Egypt (2nd edn.). Cambridge: Cambridge University Press. 